\title{
Application of a single-cell isolation technique to studies of carbon assimilation by the subtropical silicoflagellate Dictyocha perlaevis*
}

\author{
Satoru Taguchi \& Edward A. Laws \\ Hawail Institute of Marine Biology \& Department of Oceanography, University of Hawaii at Manoa, 1000 Pope Road, Honolulu, \\ Hawaii 96822, USA
}

\begin{abstract}
A single-cell isolation technique was used to study the assimilation of ${ }^{14} \mathrm{CO}_{2}$ by natural populations of the silicoflagellate Dictyocha perlaevis. The method uses a concentrated natural sample and a high activity of radioisotope. The technique facilitates physiological studies of certain species which cannot be conveniently studied in the laboratory due to difficulty in maintaining laboratory cultures. Data obtained from a subtropical embayment are used to illustrate the application of the method, and include in particular a study of carbon partitioning patterns into major polymers over the course of a diel cycle.
\end{abstract}

\section{INTRODUCTION}

Silicoflagellates are marine chrysophytes bearing a single flagellum and a star-shaped silica skeleton composed of tubular elements. They have golden-brown chromatophores and are photosynthetic. Silicoflagellates are found in most parts of the world's oceans, and have been reported as one of the most important foods for warm-water salps (e.g. Gemeinhardt 1934). However, the nutritional value of silicoflagellates has never been studied due to the difficulty of raising cultures in the laboratory. For example, van Valkenburg \& Norris (1970) have reported the only successful effort to grow Dictyocha fibula in culture, and most information about the morphological characteristics of this species and its growth rate as a function of temperature and salinity were obtained as a result of that single study. Subsequent efforts to culture $D$. fibula have been unsuccessful.

For physiological studies the difficulties in culturing silicoflagellates in the laboratory can be partially overcome by conducting experiments in the field, but only if a satisfactory method exists for separating silicoflagellates from the other seston. Rivkin \& Seliger (1981) have previously described a single cell isolation technique which involves coarse screening of a sample

- Hawaii Institute of Marine Biology, Contribution No. 699

(c) Inter-Research/Printed in F. R. Germany followed by isolation of single cells using a micropipette and dissecting microscope. Use of this technique on natural populations of silicoflagellates could greatly expand our ability to study the physiology of this important class of phytoplankton. We report here results of the use of the single-cell isolation technique to measure inorganic carbon uptake and incorporation into major polymers by natural populations of the silicoflagellate Dictyocha perlaevis Frenquelli.

\section{MATERIALS AND METHODS}

Dictyocha perlaevis was isolated on 14 Sep 1982 from a water sample collected in Kaneohe Bay, Hawaii at $157^{\circ} 47.2^{\prime} \mathrm{W}, 21^{\circ} 25.4^{\prime} \mathrm{N}$. A $35 \mu \mathrm{m}$ mesh plankton net with a $30 \mathrm{~cm}$ diameter opening was towed vertically from $2 \mathrm{~m}$ above the bottom to the surface. The total volume of water filtered was about $300 \mathrm{l}$. The sample was prescreened through a $183 \mu \mathrm{m}$ mesh net to remove large zooplankton. The following 2 experiments were then conducted immediately. First, in an approach which we will refer to as the Rivkin-Seliger method, the water collected from 1 tow was partitioned into 2 light and 1 dark bottles ( $125 \mathrm{ml}$ capacity). Each subsample was inoculated with $50 \mu \mathrm{Ci}$ of $\mathrm{NaH}^{14} \mathrm{CO}_{3}$ and incubated for $24 \mathrm{~h}$ at a constant temperature of $24^{\circ} \mathrm{C}$ and under an irradiance of $400 \mu$ Einst $\mathrm{m}^{-2} \mathrm{~s}^{-1}$ provided 
on a $12 \mathrm{~L}: 12 \mathrm{D}$ cycle by a bank of cool-white fluorescent lamps. The incubations were begun at approximately 0800 local time, and the L:D cycle was timed so as to begin the dark period $12 \mathrm{~h}$ later. One $\mathrm{ml}$ aliquots were taken from each bottle to determine the total activity of ${ }^{14} \mathrm{C}$. At the end of the incubations the contents of each bottle were concentrated with a $20 \mu \mathrm{m}$ mesh strainer and washed carefully with ${ }^{14} \mathrm{C}$-free filtered $(0.4 \mu \mathrm{m})$ seawater. $D$. perlaevis cells were then isolated using a micropipette and dissecting microscope, and washed twice with ${ }^{14} \mathrm{C}$-free filtered seawater. Finally the cells were transfered into scintillation vials for subsequent fractionation.

In a parallel experiment, Dictyocha perlaevis cells from a second tow were pipetted into 2 light and 1 dark Petri dishes containing approximately $5 \mathrm{ml}$ of filtered seawater collected from the same station. Each dish was inoculated with $5 \mu \mathrm{Ci}$ of $\mathrm{NaH}^{14} \mathrm{CO}_{3}$ and incubated in the same manner as the $125 \mathrm{ml}$ bottles. At the end of the incubation only swimming cells were pipetted out under the dissecting microscope. The cells were washed twice with ${ }^{14} \mathrm{C}$-free filtered seawater and transfered into a scintillation vial. Triplicate vials contained either $1,2,4,8,16,32$ or 64 cells per vial. We will refer to this second approach in which only swimming cells were pipetted from the Petri dishes as the modified Rivkin-Seliger method. All vials then received an addition of $10 \mathrm{ml}$ of scintillant (Amersham $\mathrm{ACS}$ ) and were stored in the dark prior to counting on a Searle Analytic liquid scintillation counter. Quench corrections were made by the external standard ratio method.

Chlorophyll a determinations were made on duplicate samples containing at least 40 cells which had been previously isolated, serially transfered through filtered seawater, and collected on Whatman GF/C glass fiber filters. Chlorophyll a was extracted in $100 \%$ acetone and measured on a Turner fluorometer using the procedures recommended by Holm-Hansen et al. (1965).

On 2 other occasions a water sample from the same station was concentrated and incubated in two $125 \mathrm{ml}$ light bottles under conditions similar to those used in the first experiment. Dictyocha perlaevis cells were isolated from aliquots taken from the 2 bottles after 6 , 12 and $24 \mathrm{~h}$. After the $D$. perlaevis cells had been isolated and placed in scintillation vials, a differential extraction technique first employed by Morris et al. (1974) was used to partition the recently assimilated carbon between protein, polysaccharide, lipid, and small molecular weight intermediate compounds. The procedure was similar to that outlined in DiTullio \& Laws (1983). Three $\mathrm{ml}$ of a $2: 1$ (v:v) chloroform : methanol mixture were added to each vial, and the vials vortexed for $1 \mathrm{~min}$ to extract the lipids and small molecular weight intermediate compounds. The contents of each vial were then filtered through a GF/C glass fiber filter, and the residue washed 3 times with $3 \mathrm{ml}$ of the chloroform: methanol mixture to remove any remaining lipid or intermediate compounds. The residue was resuspended in $3 \mathrm{ml}$ of $5 \%$ trichloroacetic acid (TCA) and heated at $85^{\circ} \mathrm{C}$ for $30 \mathrm{~min}$ to solubilize polysaccharides, and nucleic acids and to precipitate protein. After acid hydrolysis the slurry was filtered through another $\mathrm{GF} / \mathrm{C}$ filter and rinsed with $2 \mathrm{ml}$ of cold $\left(0^{\circ} \mathrm{C}\right) 5 \%$ TCA. The filtrate obtained from the chloroform: methanol extraction was transfered into a separatory flask and $3 \mathrm{ml}$ of $0.88 \% \mathrm{KCl}$ was added.

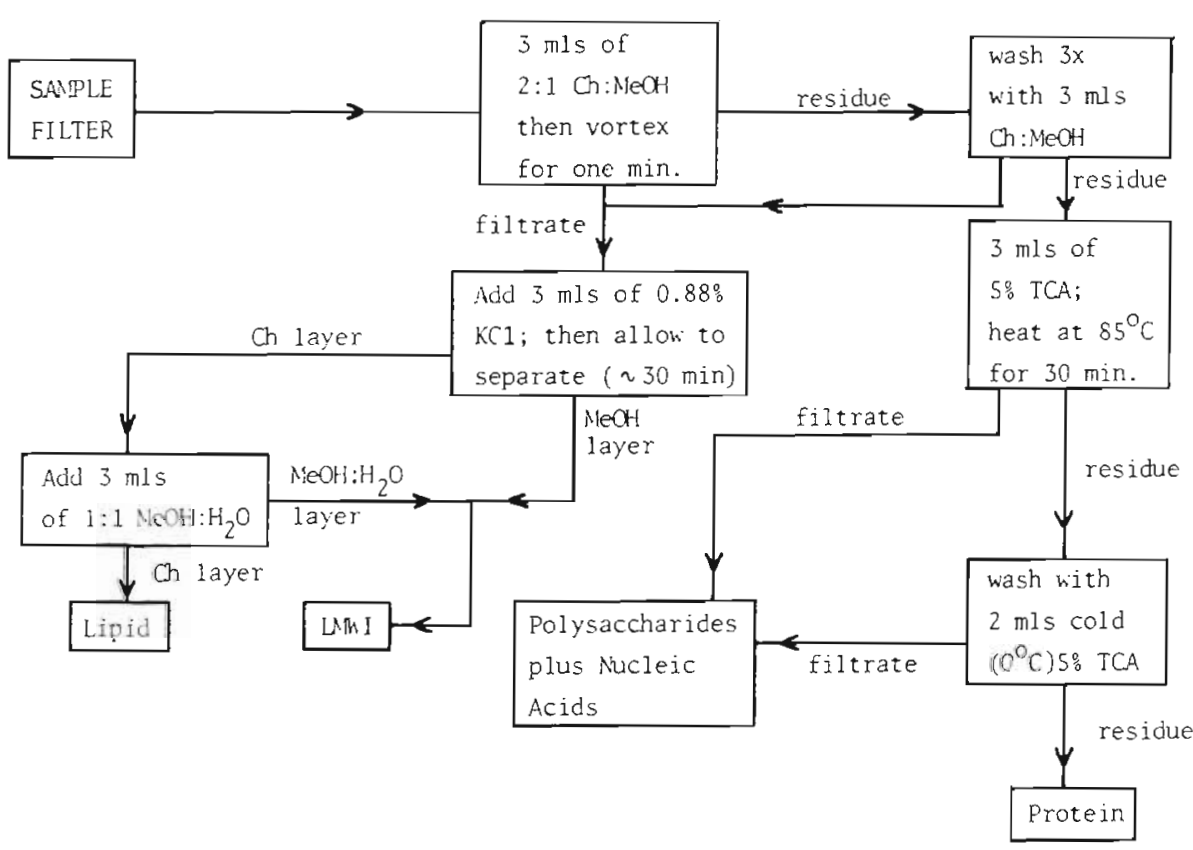

Fig. 1. Flow diagram of solvent extraction procedure to separate protein, polysaccharide, lipids, and low molecular weight intermediate compounds. Chloroform $=\mathrm{Ch}_{i}$ methanol $=\mathrm{MeOH}_{\text {i low }}$ molecular-weight intermediates $=\mathrm{LMWI}$ 
After separation was complete, the 2 layers were transfered into separate scintillation vials. The chloroform layer was then transfered back to a separatory flask, and $3 \mathrm{ml}$ of a $1: 1(\mathrm{v}: \mathrm{v})$ methanol: water mixture was added for a final wash and the immiscible solvents separated. The water-methanol layer was then combined with the original methanol layer. The fractionation technique thus separated the cell material into TCA-insoluble compounds (protein), TCA-soluble compounds (polysaccharide plus nucleic acids), chloroform soluble compounds (lipid) and methanolwater soluble compounds (low molecular weight intermediates). The volume of each of the liquid fractions was reduced by evaporating the samples at room temperature for $16 \mathrm{~h}$ before addition of the scintillant. A flow diagram of the separation procedure is indicated in Fig. 1. If 6 samples are processed at a time, 24 samples can be processed in an $8 \mathrm{~h}$ work-day. Scintillation counting procedures were identical to those used in the previous experiment.

\section{RESULTS}

Table 1 provides a comparison of results obtained with the original and modified Rivkin-Seliger techniques. A regression analysis of DPM vial-1 against cells vial $^{-1}$ gave virtually identical results, and in both cases the relationship was highly linear $(r=0.999)$. The $\mathrm{Y}$-intercepts of the regression equations were not significantly different from the radioactivity of the dark bottles.

Fig. 2 and Table 2 give a good indication of the feasibility of using the carbon partitioning technique

Table 1. Results of linear regression analysis (cells vial ${ }^{-1}$ vs DPM vial ${ }^{-1}$ ) of the original method of Rivkin \& Seliger (1981) and the modified Rivkin-Seliger method

\begin{tabular}{|lcc|}
\hline \multirow{2}{*}{ Parameters } & \multicolumn{2}{c|}{ Method } \\
& Original & Present \\
\hline Y-intercept & 30.9 & 31.2 \\
Slope & 15.9 & 16.2 \\
$\mathrm{r}$ & 0.999 & 0.999 \\
\hline
\end{tabular}

Table 2. Comparison of sum of 4 fractions and unfractionated total DPM

\begin{tabular}{|crrc|}
\hline $\begin{array}{c}\text { Cell numbers } \\
\text { vial }^{-1}\end{array}$ & $\begin{array}{c}\text { Sum of } 4 \\
\text { fractions }\end{array}$ & $\begin{array}{r}\text { Unfractionated } \\
\text { total }\end{array}$ & $\begin{array}{c}\text { Ratio of } \\
\text { sum to total }\end{array}$ \\
\hline 8 & 1,769 & 1,698 & 1.04 \\
16 & 4,038 & 4,129 & 0.98 \\
32 & 7,962 & 8,216 & 0.97 \\
64 & 15,301 & 14,998 & 1.02 \\
\hline
\end{tabular}

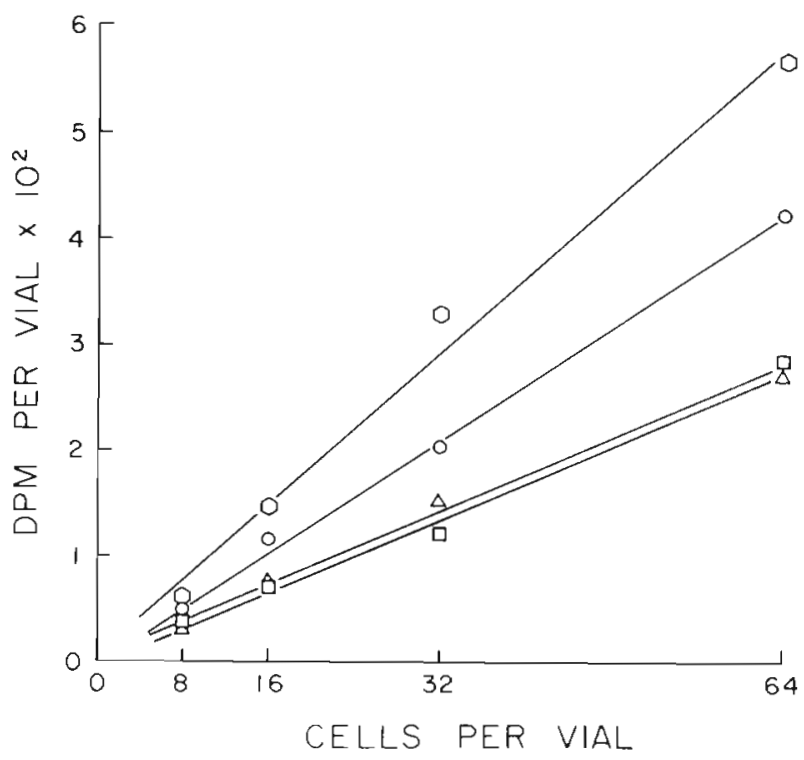

Fig. 2. Dictyocha perlaevis. Rate of ${ }^{14} \mathrm{CO}_{2}$ incorporation into protein $(O)$, polysaccharide $(\neg)$, lipids $(\Delta)$, and low-molecularweight metabolites $(O)$ as a function of the number of isolated cells vial ${ }^{-1}$. Protein: $Y=-32+66 X(r=0.998)$; polysaccharide: $\mathrm{Y}=-28+43 \mathrm{X}(\mathrm{r}=0.995)$; lipids: $\mathrm{Y}=50+42 \mathrm{X}(\mathrm{r}$ $=0.996)$; low-molecular-weight metabolites: $Y=92+88 X$ $(r=0.995)$

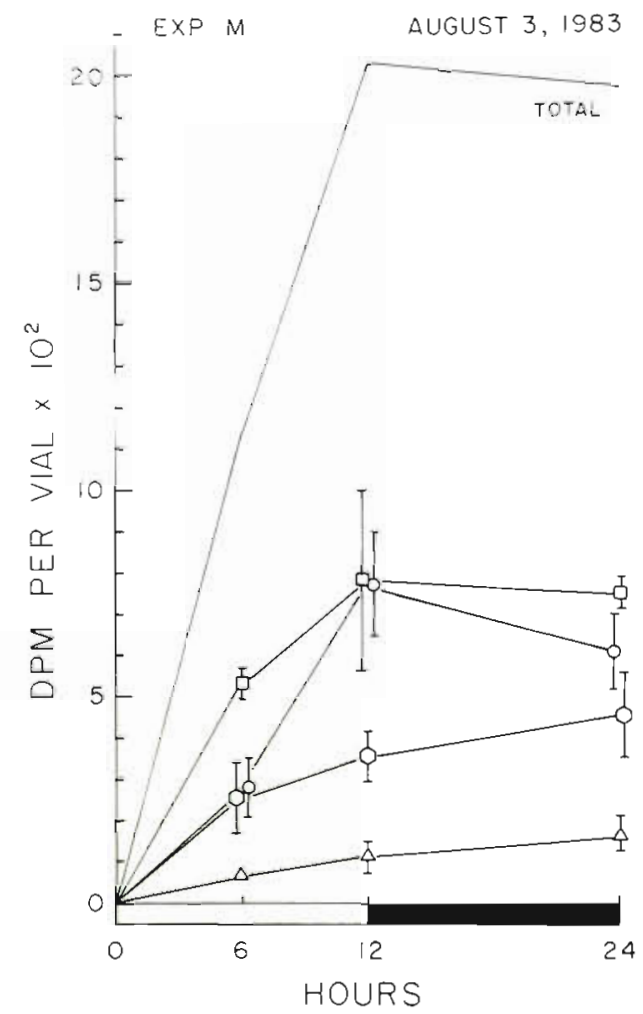

Fig. 3. Dictyocha perlaevis. Rate of ${ }^{14} \mathrm{CO}_{2}$ incorporation into protein $(O)$, polysaccharide $(\square)$, lipids $(\Delta)$ and low-molecularweight metabolites $(0)$ as a function of time of $12 \mathrm{~L}: 12 \mathrm{D}$ light cycle incubation. White and black portions on X-axis represent light and dark periods. Each value is mean \pm 1 standard deviation 
in conjunction with the Rivkin-Seliger isolation method. Due to the low radioactivity compared to blanks and a high variability of radioactivity between samples with 4 or fewer cells per vial, only data from vials with 8 or mare cells were fitted to a linear regression line. All regression slopes in Fig. 2 were highly significant $(p<0.01)$, and the sum of the ${ }^{14} \mathrm{CO}_{2}$ incorporation rates into the 4 fractions was not significantly different from the rate determined from unfractionated controls (Table 2).

In a final experiment on $3 \mathrm{Aug} 1983{ }^{14} \mathrm{CO}_{2}$ incorporarion rates for Dictyochea perlaevis were measured into major polymers using triplicate vials containing 10 cells each. The results are shown in Fig. 3 and Table 3. Total uptake rates were almost identical during the first and second $6 \mathrm{~h}$ of the photoperiod. Respiration and excretion losses resulted in a slightly negative incorporation rate during the dark period.

Table 3. Percent protein, polysaccharides, lipids, and lowmolecular-weight metabolites of total ${ }^{14} \mathrm{CO}_{2}$ uptake at the end of light and dark period

\begin{tabular}{|lcccc|}
\hline Protein & $\begin{array}{c}\text { Poly- } \\
\text { saccha- } \\
\text { rides }\end{array}$ & Lipids & $\begin{array}{c}\text { Low-molecu- } \\
\text { lar-weight } \\
\text { metabolites }\end{array}$ \\
\hline Light & 31.1 & 43.0 & 5.8 & 20.1 \\
Dark & 30.7 & 38.0 & 8.1 & 23.1 \\
\hline
\end{tabular}

\section{DISCUSSION}

The Rivkin-Seliger method was originally applied to species of coastal dinoflagellates, but was later proven to work for presumably more fragile oceanic dinoflagellates (Rivkin et al. 1984). The results reported here confirm the validity of the cell isolation technique with one of the most fragile marine phytoplankton species. In particular, the original Rivkin-Seliger method, in which no effort was made to discriminate between motile and non-motile cells, and the modified Rivkin-Seliger method, in which only motile cells were pipetted into scintillation vials, gave virtually identical results (Table 1). The good agreement between the original and modified Rivkin-Seliger methods is noteworthy, since the cells were collected in net tows, and the possibility exists that at least some cells were stressed in the process of collection. However, there was no apparent difference between the amount of ${ }^{14} \mathrm{CO}_{2}$ assimilated by Dictyocha perlaevis cells which were clearly motile at the end of the $24 \mathrm{~h}$ incubation, and those cells which showed no evidence of motility.

The photosynthetic rate of Dictyocha perlaevis cells on 14 Sep 1982 was $2.0 \mathrm{gC}(\mathrm{g} \mathrm{Chl} \mathrm{a})^{-1} \mathrm{~h}^{-1}$ during the photoperiod, a figure which is well within the range of
0.8 to 6.2 cited by Malone (1980) for netplankton lightsaturated photosynthetic rates. The estimated biomass and ${ }^{14} \mathrm{CO}_{2}$ uptake rate of $D$. perlaevis was $608 \mathrm{pg} \mathrm{Chl}$ a $\mathrm{l}^{-1}$ and $1.23 \mathrm{ngC}^{-1} \mathrm{~h}^{-1}$, respectively. This represented 53 and $36 \%$ of the corresponding netplankton (35 $\mathrm{m}$ ) measurements, respectively. Thus the photosynthetic rates of $D$. perlaevis cells appear to be comparable to that of other netplankton in Kaneohe Bay. We conclude that all of our data are consistent with the assumption that the Rivkin-Seliger cell isolation technique provides a satisfactory means for studying the physiology of these fragile silicoflagellates in the field.

Since Morris et al. (1974) combined the standard ${ }^{14} \mathrm{CO}_{2}$ method (Strickland \& Parsons 1972) with the carbon partitioning method of Roberts et al. (1963) to estimate the incorporation rate of ${ }^{14} \mathrm{CO}_{2}$ into major polymers, the carbon partitioning technique has become a promising method for studying the physiology of phytoplankton (DiTullio \& Laws 1983, Redalje \& Laws 1983, Terry et al. 1983, Cuhel et al. 1984). Recently there has been some controversy regarding the incorporation of ${ }^{14} \mathrm{CO}_{2}$ into lipids by polar species (Smith \& Morris 1980, Barlow \& Henry 1982, Li \& Platt 1982). Differences in species composition have been suggested as a possible explanation for the discrepancy of carbon assimilation into lipid (Li \& Platt 1982). However, only general floristic descriptions are available with which to check this hypothesis. The feasibility of using the Rivkin-Seliger cell isolation technique to study carbon partitioning by individual species is therefore of interest. The results shown in Fig. 2 and Table 2 indicate that ${ }^{14} \mathrm{CO}_{2}$ incorporation into major polymers can be precisely determined for Dictyocha perlaevis with the Rivkin-Seliger technique when as few as 8 cells are placed into triplicate vials after an incubation of $6 \mathrm{~h}$ or more.

In the field experiment summarized in Fig. 3, the fact that total uptake rates were very similar during the first $6 \mathrm{~h}$ and last $6 \mathrm{~h}$ of the photoperiod suggests that the results were probably not biased by bottle confinement artifacts. The insignificant rate of protein synthesis during the dark period presumably reflects the lack of carbon storage products at the end of the photoperiod (Terry et al. 1983, Cuhel et al. 1984). The percentage of ${ }^{14} \mathrm{CO}_{2}$ incorporated into protein suggests that the cells were growing at a rate equal to about $45 \%$ of the maximum possible rate at the prevailing temperature (DiTullio \& Laws 1983).

We conclude that the Rivkin-Seliger technique can be successfully applied to species as fragile as silicoflagellates, and that the carbon partitioning approach of Morris et al. (1974) can be combined with the Rivkin-Seliger cell isolation method to facilitate physiological studies of individuals species of algae in the 
field. This fact may have profound implications in physiological ecology if species are found that have drastically differently carbon assimilation patterns to other species (e.g. Smith \& Morris 1980). Knowledge in this area in conjunction with microscopic analysis of the species composition present at an experimental site would prove invaluable in deciphering data that are both temporally and spatially distinct.

\section{LITERATURE CITED}

Barlow, R. G., Henry, H. L. (1982). Patterns of carbon assimilation in phytoplankton from the Southern Ocean. Fish. Bull. Un.S. Afr. 16: 25-29

Cuhel, R. L., Orther, P. B., Lean, D. R. S. (1984). Night synthesis of protein by algae. Limnol. Oceanogr. 29: $731-744$

DiTullio, G. R., Laws, E. A. (1983). Estimates of phytoplankton $\mathrm{N}$ uptake based on ${ }^{14} \mathrm{CO}_{2}$ incorporation into protein. Limnol. Oceanogr. 28: 177-185

Gemeinhardt, K. (1934). Die Silicoflagellaten des Sudatlantischen Ozeans. Wiss. Ergebn. dt. atlant. Exped. Meteor

Holm-Hansen, O., Lorenzen, C. J., Holmes, R. N., Strickland, J. D. H. (1965). Fluorometric determination of chlorophyll. J. Cons. perm. int. Explor. Mer 30: 3-15

Li, W. K. W., Platt, T. (1982). Distribution of carbon among photosynthetic end-products in phytoplankton of the eastern Canadian Arctic. J. Phycol. 18: 466-471

Malone, T. C. (1980). Algal size. In: Morris, I. (ed.) The physiological ecology of phytoplankton. Univ. of California Press, Berkeley, p. 433-463
Morris, I., Glover, H. E., Yentsch, C. S. (1974). Products of photosynthesis by marine phytoplankton: the effect of environmental factors on the relative rates of protein synthesis. Mar. Biol. 27: 1-9

Redalje, D. G., Laws, E. A. (1983). The effects of environmental factors on growth and the chemical and biochemical composition of marine diatoms. I. Light and temperature effects. J. exp. mar. Biol. Ecol. 68: 59-79

Rivkin, R. B., Seliger, H. H. (1981). Liquid scintillation counting for ${ }^{14} \mathrm{C}$ uptake of single algal cells isolated from natural samples. Limnol. Oceanogr. 26(4): 780-785

Rivkin, R. B., Swift, E., Biggley, W. H., Voytek, M. A. (1984) Growth and carbon uptake by natural populations of oceanic dinoflagellates Pyrocystis noctiluca and $P$. fusiformis. Deep Sea Res. 31(4): 353-367

Roberts, R. B., Cowie, D. B., Abelson, P. H., Bolton, E. T., Britten, R. J. (1963). Studies of biosynthesis in Escherichia coli. Carnegie Institution of Washington Publication 607, Washington, D.C.

Smith, A. E., Morris, I. (1980). Pathways of carbon assimilation in phytoplankton from the Antarctic Ocean. Limnol. Oceanogr. 25: 865-872

Strickland, J. D. H., Parsons, T. R. (1972). A practical handbook of seawater analysis. Bull. Fish. Res. Bd Can. 167 : $1-311$

Terry, K. L., Hirata, J., Laws, E. A. (1983). Light-limited growth of two strains of the marine diatom Phaeodactylum tricornutum Bohlin: chemical composition, carbon partitioning and the diel periodicity of physiological processes. J. exp. mar. Biol. Ecol. 68: 209-227

Van Valkenburg, S. D., Norris, R. E. (1970). The growth and morphology of the silicoflagellate Dictyocha fibula Ehrenberg in culture. J. Phycol. 6: 48-54 